Agro Ekonomi Vol. 28/No. 2, Desember 2017

\title{
THE DETERMINANTS OF PADDY FIELD CONVERSION IN TIMOR ISLAND, EAST NUSA TENGGARA PROVINCE (NTT)
}

\author{
Faktor-Faktor Penentu Konversi Padi di Pulau Timor, \\ Provinsi Nusa Tenggara Timur (NTT)
}

\author{
Prischa Lulan ${ }^{1}$, Dwidjono Hadi Darwanto ${ }^{2}$, Slamet Hartono ${ }^{2}$ \\ ${ }^{1}$ Student of Postgraduate Program of Faculty of Agriculture, Universitas Gadjah Mada \\ ${ }^{2}$ Professor of Faculty of Agriculture, Universitas Gadjah Mada \\ ${ }^{3}$ Lecturers of Faculty of Agriculture, Universitas Gadjah Mada \\ ${ }^{1,2,3}$ Department of Agriculture Socio Economic, Faculty of Agriculture, \\ Universitas Gadjah Mada \\ Jl. Flora, Bulaksumur, Kec. Depok, Kabupaten Sleman, \\ Daerah Istimewa Yogyakarta, 55281 \\ phika.lulan13@gmail.com
}

\begin{abstract}
The objectives of this research are: (1) to investigate the trend of paddy fields on Timor Island and (2) to know the determinants of the conversion of paddy fields on Timor Island. Timor Island consists of several districts such as Kupang District, South Central Timor District (TTS), North Central Timor District (TTU), Belu District and Kupang City. In fact, they are the main rice-producing areas in the Timor Island, so they have an important role in the supplying sufficient for locals. However, the regions are slowly started to be converted to non-paddy-field use such as new settlements and other infrastructure development along with the current economic development. The basic method used in this research was descriptive analysis and the location of research was determined purposively because this location was based on the consideration that there was a high growth of non-agricultural sectors in Timor Island; making it vulnerable to the reduction of paddy field area. The data used was secondary data (2005-2014). The results showed that (1) the trend of rice field in Timor Island is not significant with time variable. (2) The analysis of determinants of paddy field area in Timor Island using multiple linear regression with Ordinary Least Square (OLS) method indicated that the factors affecting the conversion of wetland in Timor Island significantly are the variable of building area and the number of industries.
\end{abstract}

Keywords : field conversion, multiple regression, trend

\section{INTISARI}

Penelitian ini bertujuan untuk: (1) mengetahui trend luas lahan sawah di Pulau Timor dan (2) mengetahui faktor-faktor penentu konversi lahan sawah di Pulau Timor. Pulau Timor terdiri dari beberapa kabupaten seperti Kabupaten Kupang, Kabupaten Timor Tengah Selatan (TTS), Kabupaten Timor Tengah Utara (TTU), Kabupaten Belu dan Kota Kupang adalah beberapa kabupaten penghasil padi utama di kawasan Pulau Timor, sehingga mempunyai peranan penting dalam pemenuhan kebutuhan pangan masyarakatnya. Namun seiring dengan perkembangan ekonomi di beberapa kabupaten di Pulau Timor perlahan mulai dikonversi menjadi penggunaan non-sawah seperti permukiman baru dan pembangunan infrastruktur lainnya. Metode dasar yang digunakan dalam penelitian 
ini adalah metode deskriptif analisis dan lokasi penelitian ditentukan secara sengaja atau purposive sampling disasarkan pada pertimbangn bahwa adanya pertumbuhan yang tinggi dari sektor non-pertaniansehingga rentan terhadap pengurangan areal sawah. Data yang digunakan adalah data sekunder (2005-2014). Hasil penelitian menunjukkan mengenai trend lahan sawah di Pulau Timor tidak dsignifikan dengan variabel waktu. Untuk hasil analisis faktor - faktor penentu luas lahan sawah di Pulau Timor menggunakan regresi linear berganda dengan metode Ordinary Least Square $(O L S)$. Berdasarkan hasil analisis regresi linear berganda tersebut, faktor-faktor yang berpengaruh nyata terhadap konversi lahan sawah di Pulau Timor yaitu variabel luas lahan bangunan dan jumlah industri.

Kata Kunci : konversi lahan, regresi berganda, tren

\section{INTRODUCTION}

A plot of land can be used for variety of purposes that are often non-compatible. Hence, it emerges competition in various alternative uses and allocations in its utilization (Anwar, 1993). In agriculture, land is the most important resource, both for farmers and for agricultural development. It is based on the fact that in Indonesian agricultural activities are still based on land. Indonesia as an agricultural country, which is set in Law No. 41 of 2009 on Sustainable Food-Crop Agricultural Land Protection, needs to ensure the sustainable provision of agricultural land as a source of decent work and livelihood for humanity by maintaining the balance, progress, and unity of the national economy.

However, with the economic and industrial development as well as the population growth in Indonesia have caused the conversion, fragmentation, and degradation of agricultural land that threatens the territory's carrying capacity nationally in maintaining self-reliance, food security and sovereignty. Maintaining the balance, progress, and unity of the national economy. Irawan et al (2002: 119) asserted that the conversion of agricultural land in essence occurs as a result of competition in land use between agriculture and non-agricultural sectors. The constant availability of land in a region, faced with rapidly increasing demands, leads to an interaction between demand and supply of land, then generating land-use patterns that lead to profitable activities (Nasoetion \& Winoto, 1996).

Agricultural land, especially rice fields, has economically high selling price because it is usually located in certain developing location. However, for farmers and farm laborers, the conversion of paddy fields is a problem because they cannot switch jobs. Farmers tend to be trapped by the limited employment opportunities which could lead to further complicated social problems.

Rice is an important staple food of the Indonesian population whose role is 
a major concern, given that the shrinking of paddy fields due to land conversion causes the area of rice harvest to fall by $2.2 \%$ per year and the rate of growth of paddy production in densely populated areas decreased by $1.1 \%$ per year. This situation suggests that efforts to increase rice production should be encouraged (Ken, 2010).

NTT Province is one of the archipelago provinces consisting of several islands, including Flores Island, Sumba Island, Palue Island, Alor Island, Lembata Island, Rote Island, Sabu Island, Adonara Island, Solor Island, Komodo Island and Timor Island. The Timor Island is an island in the southern part of the archipelago, divided between the independent state of East Timor and the West Timor Region, part of the Indonesian province of NTT.

The largest contribution is dominated by the agricultural sector with a contribution to the PDRB of Timor Island in 2014 (NTT dalam Angka, 2015). The agricultural sector is dominant in Timor Island's economy because it is the main livelihood of some communities on Timor Island. Currently, the food consumption pattern in Timor Island that originally consumes non-rice food (local food such as maize and tubers) is starting to shift to rice as a single staple food (Leki, 2010). It is in accordance with Mubyarto (1977), who stated that in the long run rice will remain as the staple food of the Indonesian population, so that rice production policy will remain as the core policy in agricultural development.

Paddy fields in some areas of Timor Island such as Kupang District, South Central Timor District (TTS), North Central Timor District, Belu District and Kupang City are slowly starting to be converted to non-paddy-field use such as new settlements and other infrastructure development (BPS NTT, 2015). According to Ransastra and Budhi (1997), conversion of agricultural land to non-agricultural use can occur directly or indirectly. Conversion is directly due to the decision of the landowners to convert their agricultural land to other uses such as industry, housing, advice and infrastructure.

Land that was originally used for cultivating media, slowly began to change into multi-use functions. Changes in agricultural land use to non-farming are known as land conversion or land conversion. Sumaryanto (1995) said the implications of uncontrolled conversion of rice paddies could threaten the food supply capacity, and even in the long term can cause social harm.

Wet land conversion to nonagricultural purposes is a choice taken by farmersrationaay within a circumtances where the size of land holding is squeezing over time, and where farm activities could not give adequate returns (Ken, 2001). Some of the consequences of the rate of economic growth that is the increase 
in population concentration has a great consequence on the provision of facilities, which in turn brings great consequences to the use of space or land serta housing demand and economic center growth also accelerated as urban development began to reach the suburbs (Budi, 2015).

The conversion of paddy fields in Timor Island is certainly closely related to local government policies that provide facilities to non-agricultural sectors to encourage regional development. The development of the industrial sector and the service sector (education, tourism and other supporting infrastructure) are causing land demand for these sectors to increase.

In an effort to increase rice production, one of the priority problems that occupied to be studied is the change of the paddy area use to non-rice field. The conversion of agricultural land to non-rice field is in the form of land use for housing, industrial estate and facilities and infrastructure to support economic activities and transportation as an example of a road that grew longer and longer.

Based on the research that has been done by Ilham et.al. (2004), economic factors that affect the conversion of paddy fields in the micro scope are the price of the land, economic activity of a region, the development of settlements and the competitiveness of agricultural products. Besides that, the land conversion macro scope is positively correlated with GDRP growth and negatively correlated with farmer exchange rate.

The impact of the conversion of paddy field to non-rice field is the decreasing of agricultural productivity which can be seen from the decreasing of paddy production then the loss of paddy and finally will affect the availability of rice. Knowing the impact of wet land conversion can be done anticipatory action or improvement of the impacts caused, one of them through controlling the conversion of paddy fields. To perform such control, it is necessary to know the factors that affect the conversion of paddy fields. This study aims to determine the trends of paddy field area and the factors affecting the conversion of paddy fields in Timor Island, East Nusa Tenggara Province (NTT).

\section{METHODS}

The basic method employed in this research was descriptive analysis method, which is a method in examining the status of a group of people, an object, a set of conditions, a system of thought, or a class of events in the present. The aim was to make a systematic, factual and accurate description, image or painting of the facts, traits and relationships among the phenomena investigated (Suharsimi, 2005). The location of the research was determined purposively or using purposive sampling, which is a determination of research areas that are deliberately selected 
by considering certain things, according to the purpose of the research (Sugiyono, 2012). The research sites were conducted in Timor Island. The determination of research location was done intentionally (purposive).

The selection of this location was based on the consideration that there is a high growth of non-agricultural sectors in Timor Island; making it vulnerable to paddy field area reduction. The development of supporting infrastructures that are continuing and growing bigger resulted in conversion of paddy fields as a source of rice production can not be avoided.

The type of data used in this study was secondary data which were quantitative data including time series data within the period from 2005 to 2014 . The data obtained from the Regional Land Agency of NTT Province, as well as related institutions such as: Agricultural Office of NTT Province, Central Bureau of Statistics of NTT Province. This study also explored information to clarify the existing data including other information related to the objectives of the research. The determination of variables is based on the data availability.

\section{Analysis Method}

To analyze the trend of paddy field area in Timor Island was calculated using trend analysis. Trend analysis is a common trend model for time series data. Trend analysis is an analysis used to observe data trends thoroughly over a fairly long period of time. Trend can be used for a method of analysis aimed at conducting a future forecast or forecast of the weather (Subagyo, 1986). To do a good forecasting it takes a lot of information (data) is quite a lot and observed in a relatively long period, so the results of the analysis can be known until large fluctuations occur and what factors affect the change.

Theoretically, in time series analysis the most decisive is the quality or accuracy of the information or data obtained as well as the time or period of the data collected. If the data collected is more numerous then the better the estimate or forecasting obtained. Conversely, if the data collected less then the result of estimation or forecasting will not good.

Trend or often called secular trend is the average change (usually every year) in the long run based on time-series data (time series). If the indicated symptoms go up then the trends possess show the average increase and vice versa.

Trend estimation using linear trend analysis with Ordinary Least Squares Method (OLS) is formulated as follows (Subagyo, 1986):

$\hat{Y}=a+B x$

Where :

$\hat{Y} \quad$ : The value of paddy field area trend

a : Constant numbers 
b : Slope of line slant

$\mathrm{X}$ : Time (year)

Meanwhile, the factors that influence paddy field conversion were analyzed using multiple linear regression and estimated by using Ordinary Least Squares (OLS) method. Regression method is an estimation method that studies how the influence of one variable independent (free) to the dependent variable (not free). In the modern sense, regression is the study of how independent variables are influenced by one or more dependent variables with the aim of estimating and /or predicting the average value of dependent variables based on the value of the independent variables known (Gujarati, 2012).

The determinants of paddy field conversion used in this study were Population (X1), real GRDP of non-agricultural sector (X2), labour of agriculture sector (X3), building area (X4), number of industry (X5) and length of road (X6).

The estimated regression model is:

$$
\begin{aligned}
\mathrm{YK}= & \beta_{0}+\beta_{1} \mathrm{PDKK}_{\mathrm{t}}+\beta_{2} \mathrm{P} \mathrm{D} \mathrm{R} \mathrm{B}_{\mathrm{t}}+\beta \\
& { }_{3} \mathrm{TKP}_{\mathrm{t}}+\beta_{4} \mathrm{LLB}_{\mathrm{t}}+\beta_{5} \mathrm{JI}_{\mathrm{t}}+\beta_{6} \mathrm{PJLN}_{+} \varepsilon
\end{aligned}
$$

Where :

YK : Area of paddy fields converted per year $(\mathrm{Ha})$

PDKK: Population (People)

PDRB : Real GDRP of non Agricultural Sector $(\mathrm{Rp})$

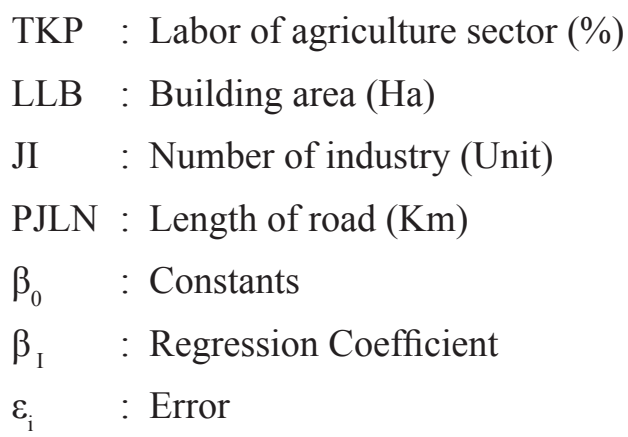

\section{RESULTS AND DISCUSSION}

\section{Trend Analysis of Paddy Field Area in}

\section{Timor Island NTT}

Trend analysis is an analysis that sees the long-term uptrend or downtrend movement obtained from the average changes over time and the value is smooth. Periodic data trends can be in form of trends that increase and decrease smoothly. An uptrend is called a positive trend and a downtrend is called a negative trend. Trends show relatively long and stable time changes.

Trend analysis is used to know the development of paddy area from time to time based on time series data. The area of paddy fields in Timor Island in the period of 2005 to 2014 fluctuated. Graphically, the development of paddy field area in Timor Island can be described as follows:

Figure 1 shows that during the period of 2005 - 2014 on Timor Island there was widespread fluctuation of wetland area with decreasing tendency. In the periods of 2005 was above the trend line and then in 2006-2007 showed a declining 


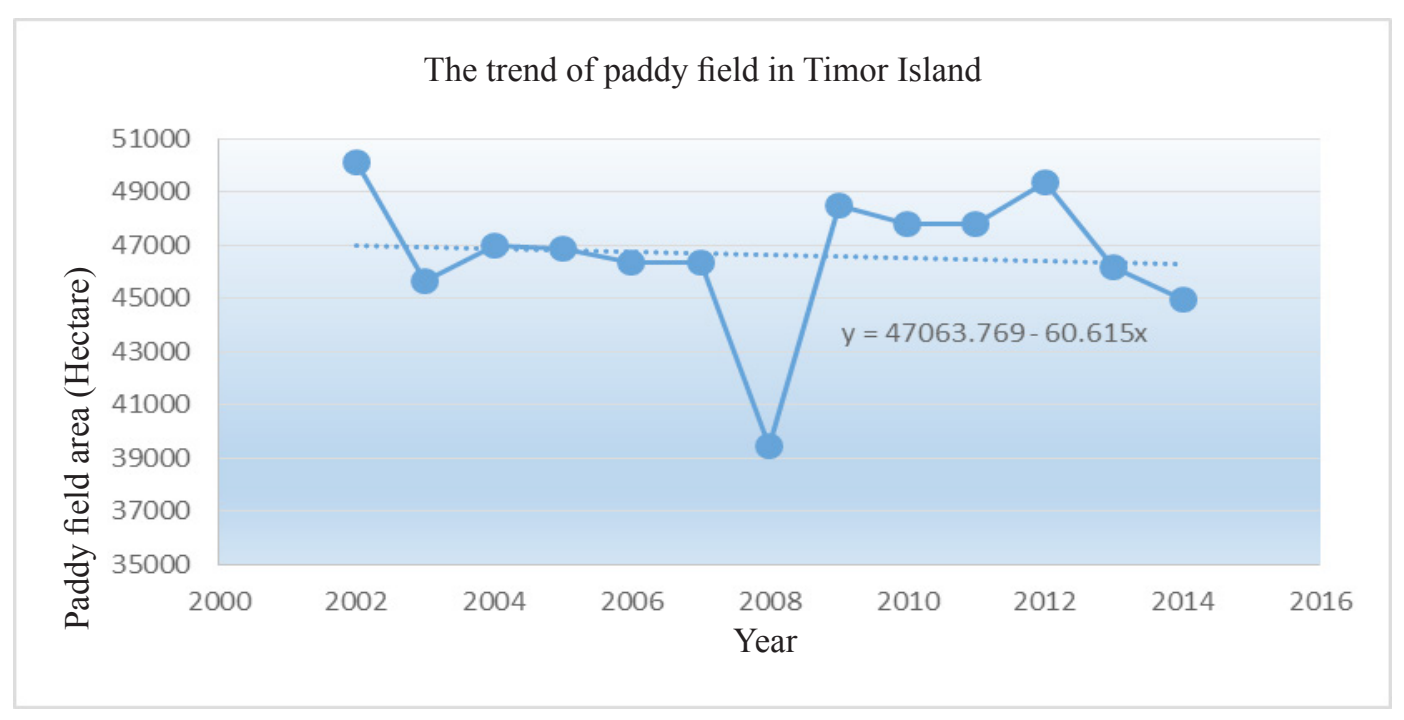

Figure 1. The Development of Paddy Field Area in Timor Island in 2005-2014

Table 1. Result of Analysis of Linear Trend of Paddy field Area in Timor Island 2005-2014

\begin{tabular}{ccc}
\hline Parameters & Coefficient & t-count \\
\hline Constanta & $47063,769^{* * *}$ & 29,442 \\
Time $(X)$ & $-60,615^{\text {ns }}$ & $-0,301$ \\
\hline $\mathrm{R}^{2}$ & & 0,008 \\
F-count & & 0,769 \\
\hline
\end{tabular}

Source: Secondary Data Analysis, 2017

movement. The next period of 2008 was a decline in wetlands accompanied by an increase in land for buildings for housing and industry and other uses, and then tended to move back above trend line in 2009 due to new paddy field printing and fluctuating up and down in 2010-2012. Then in the period 2013-2014 back down due to construction of new settlements and other infrastructure facilities (NTT dalam Angka, 2015).

Statistical analysis using linear trend analysis to find out the relationship between paddy field area in Timor Island until now obtained the following results:
From Tabel 1, it appears that the trend pattern of paddy field area in Timor Island followed a linear downtrend pattern with equation:

$\hat{Y}=47063.769-60.615 X$

The equation of linear trend of wetland area on Timor Island in 2004-2014 shows that time factor has no significant effect on wetland area. Based on the coefficient of this time factor has a negative relationship to the area of wetland, indicated by the value of the value coefficient (-).

The linear trend estimation of paddy field area in Timor Island has decreased due 
to the conversion of paddy fields that keep happening since some of the districts in the island are located around Kupang City, the capital of NTT Province, which began developing the land use for settlements and other physical development for the economic development. That condition is realistic considering the land owned by a region is fixed while the need for nonagricultural land sector is increasing so that the conversion is inevitable. Therefore, it is necessary to anticipate through regulation or land intensification efforts.

The graph of the linear trend pattern of wetland area on Timor Island is shown in Figure 2. :

\section{Determinants of Paddy Field Areas in Timor Island NTT}

Decisions on land use are strongly influenced by the accessibility of the land, the more easily accessible and affordable areas are relatively chosen as a place to engage in socio-economic activities (Wardani, 2009). One of the decisive factors in planning the development of a region, namely as a key element that determines everything then. Increased socio-economic activity in a region shows the better road infrastructure in the region. This is because the relationship between regions will be easier in the mobilization of production factors and distribution of production output.

An area with better access will influence the decision on land use. Easy access to various facilities and facilities and infrastructure that support good socioeconomic activities will be interesting to use as a place of business or residence as it will provide greater benefits. But unlike the areas that have poor road infrastructure, such as areas that are less difficult to reach, often used for agricultural activities.

Ease of access to road infrastructure will affect land rental in the area will then affect

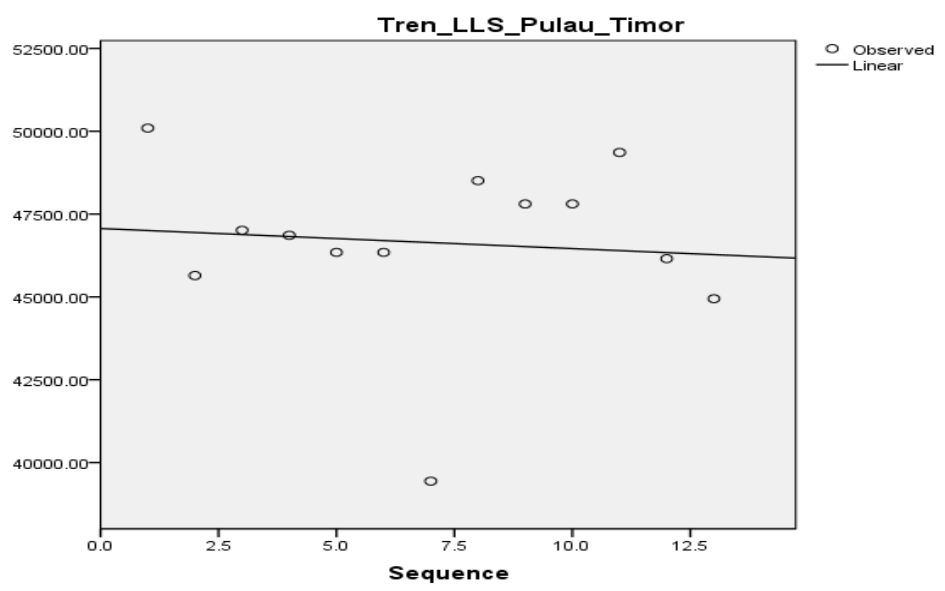

Figure 2. Estimated Land Trend in Timor Island Year 2005 - 2014 
the conversion of land to non-agricultural use. This is because the rate of land rent for non-agricultural use (in the presence of road networks) will be faster than for agricultural use. Therefore, the conversion of paddy field land will also increase along with the improvement of road infrastructure. In this case, the variable is measured by the length of road owned by a region.

The development of facilities for socio-economic activities and settlement is the effect of population growth in a region. Increasing the number of people in a region will lead to pressure from increasing population density. It will trigger an urge to expand the settlement area to the surrounding area so that there will be a change in land use. The suitable topography and natural conditions for residential areas are rice fields so that land conversion cannot be avoided.

A region in its urban growth process is usually accompanied by increasing demand for land for settlements. The demand was met by the way the construction of residential complexes in the formerly agricultural suburbs. Increased population will also impact on the increase of the workforce.

In countries undergoing transformation from the primary to secondary sectors will lead to industry, which is one of the efforts to meet the needs of employment with the opening of new factories or industries or by developing an existing industry. The development of the industry will increase the need for land so that there is an increase of land use change to non agriculture.

Real GDP of non agricultural sector is the amount of added value that produced or is the value of final goods and services produced by the non-agricultural sector within a region within a certain period. If the GRDP of the non-agricultural sector, the greater means the ability of nonagricultural sector in generating added value or produce a greater output, which means also the competitiveness of the agricultural sector is also greater.

The economic structure of a wider region will affect the economic structure of the region it covers. The economic structure can be seen from the contribution of the economic sector to the creation of GRDP in the region. The trend of transformation given economic sector from agriculture to non-agriculture causes the contribution of non-agricultural sector is greater to GRDP. The large contribution of the agricultural sector in Timor Island will also affect the economic structure of the districts / municipalities in the territorial of Timor Island. The greater the GDP will increase the conversion of paddy fields as a result of the influence of non-agricultural economic structure.

The analysis of land conversion determinants on paddy field in Timor Island was conducted to see the factors 
Table 2. The Results of Multiple Linear Regression Analysis of Paddy Field Conversion in Timor Island in 2017

\begin{tabular}{lrrr}
\hline Variable & Coefficient & \multicolumn{1}{c}{ t-count } & \multicolumn{1}{c}{ Sig, } \\
\hline Constanta & $-5386,868$ & -1.139 & $0.337^{\text {ns }}$ \\
Population $\left(\mathrm{X}_{1}\right)$ & 0.000 & -0.138 & $0.899^{\mathrm{ns}}$ \\
GDP Rill Non-Farm Sector $\left(\mathrm{X}_{2}\right)$ & 0.001 & 1.104 & $0.350^{\mathrm{ns}}$ \\
Agricultural Sector Employment $\left(\mathrm{X}_{3}\right)$ & -17.384 & -0.372 & $0.735^{\mathrm{ns}}$ \\
Building area $\left(\mathrm{X}_{4}\right)$ & 0.304 & 6.651 & $0,007^{* * *}$ \\
Number of Industries $\left(\mathrm{X}_{5}\right)$ & 116.692 & 4.771 & $0.018^{* *}$ \\
Road Length $\left(\mathrm{X}_{6}\right)$ & -0.749 & -0.899 & $0.435^{\mathrm{ns}}$ \\
\hline Adjusted $R^{2}$ & & & 0.915 \\
\hline F count & & & $17.193^{* *}$ \\
\hline Durbin Watson Test & & & 3.124 \\
\hline
\end{tabular}

Source: Secondary Data Analysis, 2017

Description: $\quad * * *$ Significant effect on the level of $99 \%$

** Significant effect on the level of $95 \%$

* Significant effect on the level of $90 \%$

that determine the land conversion with the relationship between the response variables (dependent variable) and the explanatory variable (independent variable) and also to find the relationship between the explanatory variables.

The response variables are variables of paddy field area conversion whereas the explanatory variables are Population $\left(X_{1}\right)$, GDP Rill Non-Farm Sector $\left(X_{2}\right)$, Agricultural Sector Employment $\left(\mathrm{X}_{3}\right)$, Building area $\left(\mathrm{X}_{4}\right)$ and Length of Road $\left(\mathrm{X}_{5}\right)$. Multiple linear regression analysis in this study was conducted to determine which factor among those 5 (Five) factors that mostly affected the conversion of paddy fields in Timor Island NTT.

The overall test with ANOVA table 2 shows the value of determination coefficient (adjusted R2) is 0.915, meaning that independent variable of population, real GRDP of agriculture sector, labor of agriculture sector, building area, industry number and length of road can reach $91.5 \%$ from the total factors affecting the conversion of paddy fields on Timor Island. The remaining $8.5 \%$ is determined by other variables not included in the model. The result of analysis with $\mathrm{F}$ test shows that the value of Fcount is 17.193 and Ftabel is 4.95 which means that Fcount $>$ Ftable is significant at $\alpha=$ $0.05 \%$. So that, the independent variables simultaneously significant effect on the dependent variable.

To know the influence of independent variable to dependent variable done by $t$ test. $\mathrm{T}$ test is a partial test that aims to examine the effect of certain independent variables on the dependent variable. The $t$ test is done 
by comparing the t-sig (significance) at the error rate of each independent variable affecting the dependent variable. If the value of t-sig is smaller than $\alpha$ used, it can be concluded that independent variables individually have a significant influence on the dependent variable.

The $t$ test is done by comparing the t-sig (significance) at the error rate of each independent variable that affects the dependent variable. If the value of t-sig is smaller than the $\alpha$ used, then it can be concluded that the independent variable individually has a significant effect on the dependent variable

The t-test result to see the effect of each independent variable on the conversion of rice field on Timor Island is significantly influenced by the building area and the number of industries. While real non-agricultural GRDP, the population, agricultural labor and long roads are not significant. Building area has significant effect to $\alpha=0,01 \%$ while Number of industries have significant effect to $\alpha=0,05 \%$. The value of the alleged parameter used in the wet land conversion model is its elasticity value. The coefficient or elasticity values of the building area and the number of industries are 0.007 and 0.018 , respectively

Building Area $\left(\mathrm{X}_{4}\right)$ has a significant positive effect with the elasticity of 0.304 . This shows that if the building area increased by $1 \%$ it will increase the conversion of rice fields by 0.172 hectare. This indicates that any development, especially physical development must require land. The more land area of a building in an area on Timor Island to non-agricultural use so the demand for building land is higher and what happens is the conversion of paddy fields to meet the demand.

Variable of industrial number also has a significant and positive effect to wetland area with $95 \%$ confidence level, where if there is addition of industrial amount equal to $1 \%$ it will decrease rice field area by 0.018 hectare. The most developed industrial sector in Kupang city region. During the period of industry research is growing rapidly, especially small and medium industries. Wetland is needed to meet the development of both small and medium-sized industries where more and more industries are increasingly wasted rice fields.

The variable of industrial quantity also negatively influence to wetland area with $95 \%$ confidence level, where if there is addition of industrial amount equal to $1 \%$ it will decrease wetland area equal to $0.298 \%$. The most developed industrial sector in Kupang city region. During the period of industry research is growing rapidly, especially small and medium industries. Wetland is needed to meet the development of both small and mediumsized industries where more and more industries are increasingly wasted rice 
fields. Overall, multiple linear regression model above is appropriate and fit.

In line with the results of Putri (2015) study entitled Analysis of Causes of Land Function Distribution to Agricultural Land Regency / City In Central Java Province 2003-2013, wide of residential land and number of industry has a significant and positive effect to the conversion of agricultural land in the 6 povinces of Central Java.

\section{CONCLUSION AND SUGGESTION}

\section{Conclusion}

Based on the analysis results on the trend of the paddy fields area in Timor Island NTT, it was obtained the result that the trend of paddy field was in the form of linear flat trend. The equation of linear trend of wetland area on Timor Island in 2005-2014 shows that time factor has no significant effect on wetland area. Based on the coefficient of this time factor has a negative relationship to the area of wetland, indicated by the value of the value coefficient (-).

The analysis of determinants of paddy field area in Timor Island used multiple linear regression with Ordinary Least Square (OLS) method. Based on the results of multiple linear regression analysis, the factors that significantly affected the conversion of paddy fields in Timor Island by the building area and the number of industry.

\section{Suggestion}

According to the results of the research, it is necessary to make efforts to conserve paddy fields through prevention of paddy field conversion and optimization of potential land use so that the sustainability of agriculture in Timor Island can be maintained. The building area and the number of industry have a significant effect on the conversion of paddy fields in Timor Island. Therefore, local governments should arrange and design local regulations depends on UUD Lestari about the conversion of agricultural land such as determining which land may or not be converted, or which land needs to be maintained, especially for high-yielding paddy fields. In addition, the development of appropriate agricultural technology application and the improvement of irrigation network infrastructure are needed to increase the productivity of paddy fields in order to reduce the impact of paddy field conversion resulting from land conversion.

\section{REFERENCES}

Anwar, A. 1993. Dampak Alih Fungsi Lahan sawah Menjadi Lahan Non Pertanian di Sekitar Wilayah Perkotaan. Jurnal Perencanaan Wilayah dan Kota, Nomor: 10, triwulan IV/ 2003.

Budi, Rohani. 2015. Alih Fungsi Lahan Di Perkotaan (Studi Kasus Di Kota Bandung dan Yogyakarta). Jurnal 
Pusat Pengkajian, Pengelolaan Data

dan Informasi (P3DI). Sekretariat Jendral DPR RI.

Gujarati, D. 2012. Dasar - Dasar Ekonometrika. Penerbit Erlangga. Jakarta.

Ilham, N. Y. dan Supeno, F. 2004. Perkembangan dan Faktor-Faktor Yang mempengaruhi Konversi Lahan Sawah Serta Dampak ekonominya. Jurnal Agro Ekonomi. Pusat Penelitian Sosial ekonomi Pertanian, Badan Penelitian dan Pengembangan Pertanian, Departemen Pertanian.

Irawan, B. dan S. Friyatno. 2002. Dampak Konversi Lahan Sawah di Jawa terhadap Produksi Beras dan Kebijakan Pengendaliannya. Jurnal Sosial - Ekonomi Pertanian dan Agribisnis SOCA: 2(2): 79-95.

Jamal, Erizal. 2001. Faktor-Faktor Yang Mempengaruhi Pembentukan Harga Lahan Sawah Pada Proses Alih Fungsi Lahan Sawah Ke Penggunaan Non Pertanian (Studi Kasusu di Beberapa Desa, Kabupaten Karawang, Jawa Barat). Jurnal Agro Ekonomi 19(1): 45-63.

Ken, S. 2010. Dampak Teknologi Agriculture Growth Promoting Inoculant (AGPI) Pada Usahatani
Padi Sawah Di Kabupaten Sleman. Jurnal Agro Ekonomi 17(1):81-90.

Leki, S, 2010. Kajian Kebijakan Pertanian Dalam Memenuhi Kebutuhan Dasar Penduduk Di NTT. Perkumpulan Pikul. Kupang.

Lestari, T. 2009. Dampak Konversi Lahan Pertanian Bagi Taraf Hidup Petani. Makalah Kolokium. Institut Pertanian Bogor. Bogor.

Nasoetion, L. dan Winoto. J. 1996. Masalah Alih Fungsi Lahan Pertanian dan Dampaknya terhadap Keberlangsungan Swasembada Pangan. Prosiding Lokakarya Persaingan Dalam Pemanfaatan Sumberdaya Lahan dan Air: 64 - 82.

Putri, Zara. 2015. Analisis Penyebab Alih Fungsi Lahan Pertanian ke Lahan Pertanian Kabupaten/ Kota Di Provinsi Jawa Tengah 2003-2013. Jurnal Eko-Regional, 10(1).

Rusastra dan Budhi. 1997. Konversi Lahan Pertanian dan Strategi Antisipatif dalam Penanggulangannya. Jurnal Litbang Pertanian 16(4): 107-113.

Subagyo, 1986. Forecasting, Konsep dan Aplikasi. BPFE. Yogyakarta.

Sumaryanto, N. Syafa'at, M. (1995). Analisis Kebijakan Konversi 
Lahan Sawah ke Penggunaan Non Pertanian. Jurnal Sosial Ekonomi. Pusat Penelitian Sosial Ekonomi Pertanian Badan Penelitian dan Pengembangan Pertanian. Departemen Pertanian.
Swastika, D. 2007. Analisis Kebijakan Peningkatan Produksi Padi Melalui Efisiensi Pemanfaatan Lahan pertanian di Indonesia. Jurnal Pusat Analisis Sosial Ekonomi dan Kebijakan Pertanian. 